\begin{abstract}
Iranica
Abstracta Iranica Revue bibliographique pour le domaine irano-aryen

Volume 34-35-36 | 2017

Comptes rendus des publications de 2011-2013
\end{abstract}

\title{
Charles M. Kieffer. Tabous, interdits et obligations de langage en Afghanistan
}

Johnny Cheung

\section{(2) OpenEdition \\ 12 Journals}

\section{Electronic version}

URL: http://journals.openedition.org/abstractairanica/42030

DOI: 10.4000/abstractairanica.42030

ISSN: 1961-960X

Publisher:

CNRS (UMR 7528 Mondes iraniens et indiens), Éditions de l'IFRI

\section{Electronic reference}

Johnny Cheung, "Charles M. Kieffer. Tabous, interdits et obligations de langage en Afghanistan », Abstracta Iranica [Online], Volume 34-35-36 | 2017, document 7, Online since 30 July 2017, connection on 03 October 2020. URL : http://journals.openedition.org/abstractairanica/42030 ; DOI : https:// doi.org/10.4000/abstractairanica.42030

This text was automatically generated on 3 October 2020 .

Tous droits réservés 


\title{
Charles M. Kieffer. Tabous, interdits et obligations de langage en Afghanistan
}

\author{
Johnny Cheung
}

\section{REFERENCES}

Charles M. Kieffer. Tabous, interdits et obligations de langage en Afghanistan. Wiesbaden, Reichert, 2011, 192 p. (Beiträge zur Iranistik 32)

1 Some years before his passing (after a debilitating disease), the renowned FrancoAlsatian expert in the languages spoken in Afghanistan, Charles Kieffer ( $\uparrow 12$ February 2015, Cernay, France) decided to publish his huge collection of linguistic and cultural observations that were, previously, considered not worth printing in serious academic writing. After all, they consist largely of informal expressions, curses, taboo forms, including animal references, colourful descriptions of unmentionable, if not unprintable, parts of the human anatomy and their functions in several languages ("matériaux aléatoires") which he recorded during his frequent stays, between 1957-1981 prior to and shortly after the Soviet invasion of Afghanistan.

In the first place, he (p. 39 f.) signaled the difficulties to apply a concept such as taboo (an originally Tongan concept and later popularized by the psychoanalyst Sigmund Freud) to a totally different cultural context such as Afghanistan, a largely conservative Islamic country. In its Polynesian sense, a taboo refers to the forbidden character ("caractère interdit") of an object, person or behaviour for the members of a community, whether for its sacred or its harmful properties. For his discussion of the Afghan material, Kieffer would rather define taboo according to its broader, linguistic usage of avoidance: the banning of certain words or expressions for reasons of religion, public morality or social conventions. As Islam prohibits the consumption of pork, including its feral cousin, the wild boar, the corresponding term is quite often a 
borrowing from Arabic, xinzir. Also, animals that traditionally instill great fear and apprehension in humans often receive a different designation, either a descriptive, the "terme descriptif", or an evasive, euphemistic one, the "terme d'évitement", such as the bear (descriptively: Dari bad-jenāwwar 'the bad animal') or the snake (evasively: Dari respān 'rope'; also, descriptively: Dari čamča-mār 'skimmer-snake', i.e. cobra).

Kieffer then continues to elaborate on the "terme descriptif". The reasons that certain animals have a descriptive term are varied, either because they have no history in Afghanistan, notably the pelican (Dari čamča-nōl lit. 'skimmer-beak'), or they are harmful (e.g. carrying infectious diseases or a bad omen), such as the hare (Dari xar-gūš 'large (donkey) ears'), or command a certain respect in Afghanistan, such as the spider (e.g. Kabuli tār-kaš 'thread-drawer', gilim-bāf 'rug-weaver').

4 Another chapter, called "Les interdits", is devoted to natural or physical phenomena that generally cause great fear and distress to people, such as death, poison, blindness, adverse weather conditions. It is rather jarring that this also includes the notion of sin and social faux-pas, e.g. treason, curiosity, gluttony, arrogance, and of course, the transgressions concerning sexual and moral behavior, amorous relations, dietary prescriptions (on the consumption of alcohol and pork), curses and blasphemy. These religiously or culturally determined concepts, which are evidently taught and transmitted by the elders to the young, are of a wholly different order and ought to be discussed in a separate chapter.

5 Chapter 6, labelled as "Les terminologies particulières" is a veritable hotchpotch of designations of Islamic terms, references to the position of women and matrimony in Afghanistan, practices and terms concerning childbirth, aphrodisiacs, birth control, physical relief, circumcision, prophylactic amulets, jokes and pleasantries, and finally, references to pain. One needs a lot of imagination to see a common thread in the subjects discussed in this chapter, as it contains many disparate subjects and expressions, which are, often, also not relevant to the central themes discussed in the preceding sections.

6 The main chapters are preceded by an introduction on the collection of the data by the author and concluded by "Épilogues", which gives some general remarks on Afghan culture, the forbidden words and the terminology of obligations, the questions raised by the data et al.

7 A few points of criticism may be raised here. Sometimes, one senses that the author's train of thought is allowed to meander too long over several pages, adding little to the main topic of each individual chapter. One becomes often acutely aware of the heterogenous nature of the collected material: the nagging feeling that the book is "unfinished" remains. It could have greatly benefitted by the culling of chapter 6 , or if it was followed by a more profound analysis of the concepts or ideas experienced by the different Afghan groups. One could think of a systematic comparison to the cultural traditions from the big neighbour, Iran, and, especially, to the nomadic customs introduced by Turkic and Mongolian tribes from Central Asia, perhaps in collaboration with a colleague and fellow-expert of Afghanistan. It shows that Kieffer was a great descriptive linguist, but unfortunately, not a great anthropologist. This also leads inevitably to the abstraction and simplification of the cultural traditions of the different Afghan ethnic groups to mere terms and expressions, which often leave the reader wondering about their precise functions, applicability or universality implied. I am often startled by the frequent, gross simplification of the complex reality of 
Afghanistan (consisting of a mosaic of many ethnic groups, sharp differences between religious and ethnic groups, between the urban versus the rural and nomadic life styles, etc.) portrayed in the book, and, indeed epitomized by the concluding chapter "Épilogues".

8 Regardless, this volume gives us some indispensable insight in the thoughts and conceptions of the world in the daily life of ordinary Afghans that we as foreign scholars in the 21st century have no longer access to, or cannot even hope to have a glimpse of it without the protection of armed guards in a contrived social setting.

\section{AUTHORS}

\section{JOHNNY CHEUNG}

Inalco, Mondes iranien et indien 